\title{
ベースプレート降伏により柱脚浮き上がりを許容した 10層鉄骨架構の 3 次元地震応答 \\ THREE-DIMENSIONAL SEISMIC RESPONSE OF TEN-STORY STEEL FRAMES WITH YIELDING BASE PLATES ALLOWED TO UPLIFT
}

\section{緑川光正 ${ }^{*}$, 須藤智文**, 麻里哲広***, 小豆畑 達哉****, 石 原 直 ${ }^{* * * * *}$ Mitsumasa MIDORIKAWA, Tomofumi SUDO, Tetsuhiro ASARI, Tatsuya AZUHATA and Tadashi ISHIHARA}

\begin{abstract}
Previous studies have suggested that rocking vibration accompanied with foundation uplift motion might reduce the seismic damage of buildings subjected to severe earthquake motions. In this paper, the seismic response of ten-story steel frames with columns allowed to uplift is evaluated and compared with that of fixed-base frames by numerical analyses. It is shown that the base shears in the frames with column uplift are significantly reduced as compared to the fixed-base frames, and that the vertical component of earthquake motions does not much affect the horizontal responses of uplift frames but increases slightly the uplift response displacement of uplift frames.
\end{abstract}

Keywords : Seismic Response Analysis, Ten-story Steel Frame, Uplift, Yielding Base Plate, Rocking Response 地震応答解析，10 層鉄骨架構，浮き上がり，降伏ベースプレート，ロッキング応答

\section{1. 序}

過去の地震被害調査等から，地震動を受ける建物がロッキング振 動に伴う基礎浮き上がりを生じることによって, その地震被害が軽 減される場合のあることが指摘されている例えば1) 3)。また, $\mathrm{Meek}^{4)}$, 5)は，基礎浮き上がりを伴う 1 質点系モデルを対象とし，基礎と地 盤の完全塑性衝突を仮定して基礎浮き上がりが地震時挙動に及ぼす 影響を検討し, 主にその自由振動応答を解析により明らかにすると ともに，連層耐震壁付建物を対象としてパルス応答および地震応答 を求め，基礎浮き上がりによって建物のベースシアと転倒モーメン トが大幅に低減することを示している。さらに, Chopra ら 6), 7)は, 基礎浮き上がりを伴う 1 自由度系および多自由度系構造物を対象と して，剛な地盤におけるベースシア地震応答スペクトルを導き，塔 状比の大きな場合, そして周期が 0.3 秒から 2.0 秒の範囲の場合に 応答低減が顕著になることを示している。

一方，建物に浮き上がりを許容する場合には，建物全体の水平変 位が増大し，入力地震動が極めて大きい場合には転倒するのではな いかとの懸念が指摘されることがある。しかしながら，建物程度の 大きさになると転倒に必要なポテンシャルエネルギーが大きくなる ために転倒は起こり難くなることが既往の研究 8) 10)で明らかにさ れている。

以上の知見に基づいて，地震時のロッキング振動による基礎や柱 脚の浮き上がりを意図的に許容する構造方法が提案されている 11) 15)。この構造方法の特徵としては, 岩下ら 16)や小豆畑ら 17)が指摘し
ているように，建物に浮き上がりを許容する場合，建物への地震入 カエネルギーの一部がその位置エネルギーと上下方向の運動エネル ギーに置換されるため, 建物各層の水平変形に伴う歪エネルギーが 低減されることが挙げられる。

これらの状況の下，筆者らは，鉄骨架構を対象として，簡潔な機 構により地震時に柱脚の浮き上がりを許容する構造方法を提案し, その地震応答を評価している 15), 17) 19)。この構造方法は, 後で示す ように鉄骨架構の最下層柱脚部に上部構造の降伏に先行して浮き上 がり降伏するように工夫したベースプレート（以下，BPY と呼ぶ) を配置し，ベースプレート降伏後に建物の浮き上がりを許容するも のである。これまでのところ，この構造方法は，浮き上がりを許容 することにより，またベースプレートの塑性化による履歴エネルギ 一吸収が期待できることにより，柱脚固定建物に比較してベースシ ア係数の地震応答低減効果を確保しつつ, 架構の頂部水平変位およ び浮き上がり変位をある程度抑制できることを明らかにした 15), 17), 18)。また，浮き上がりに伴う柱脚部での衝突の影響についても，浮 き上がり降伏するベースプレートがエネルギー吸収部材として機能 するために，その影響はそれほど大きくないことが実験および解析 により指摘されている ${ }^{18)}$ 。しかしながら，柱脚部浮き上がりを伴う 架構が水平 2 方向の地震動を受ける際の立体挙動を考えた時, 例え ば短辺方向で一部の柱脚部が浮き上がっている状態では，それと直 交方向（長辺方向）の地震動によって㧖れ振動が生じることが䀣念 される。柱脚部浮き上がり架構の地震時立体挙動については, 筆者

\footnotetext{
* 北海道大学大学院工学研究科 教授·工博

** (株) 竹中工務店 修士 (工学) (元北海道大学 大学院生)

*** 北海道大学大学院工学研究科 助教 $\cdot$ 博士 (工学)

$* * * *$ 国土交通省国土技術政策総合研究所 室長・博士 (学術)

***** 国土交通省国土技術政策総合研究所 主任研究官·博士(工学)

Prof., Graduate School of Eng., Hokkaido University, Dr. Eng.

Takenaka Corp., M. Eng.

(Former Grad. Student of Hokkaido University)

Asst. Prof., Graduate School of Eng., Hokkaido University, Dr. Eng.

Division Head, Nat'l Inst. for Land and Infrastr. Management, Ph. D.

Senior Res. Engr., Nat'l Inst. for Land and Infrastr. Management, Dr. Eng.
} 
ら 19)の解析例があるものの, その挙動は上下動の影響を含めて未だ 殆ど明らかにされていない。

本論文では, 10 層鉄骨架構を対象とし, 柱脚固定モデルと最下層 柱脚部に BPY を組み込んだモデルの 2 種類の立体架構モデルを用 いて非線形有限要素法による 3 次元地震応答解析を行い, 水平 1 方 向, 水平 2 方向同時, 水平・上下 3 方向同時の地震動入力を受けた 場合の弾塑性応答性状, 寸なわち, ベースシア，転倒モーメント， 頂部水平変位, 柱脚部浮き上がり変位などの時刻歴応答や最大応答 值に関する比較検討を行い, その立体挙動について考察する。

\section{2. 解析方法と解析条件}

\section{1 解析モデルと条件}

解析には 3 次元非線形有限要素法 20)を用いる。

解析対象は, 図 1 に示すように, 高さ $37.8 \mathrm{~m}, 3 \mathrm{x} 1$ スパン, スパ ン長 $6.0 \mathrm{~m}$ および $7.5 \mathrm{~m}$ の 10 層鉄骨架構 19$)$ とする。この架構は, 現 行耐震規定に従って基礎固定として設計されており, 梁降伏先行型 の崩壊機構が形成される。なお, 塔状比（高さ/スパン長）は, 短辺 方向 5.0, 長辺方向 2.1 である。

解析モデルは, 図 2(a)に示寸立体モデルとし, 柱脚固定モデル(総 節点数約 6000 , 以下 FIX モデルと呼ぶ) と柱脚浮き上がり許容の降 伏ベースプレートモデル(総節点数約 7500, 以下 BPY モデルと呼ぶ) の 2 種類とする。

図 2 に示すように, BPY と 1 階柱がシェル要素, 2 階以上の柱と 梁が梁要素の弾塑性モデルとし, 1 階柱頭部ではシェル要素と梁要 素を剛結合する。床はコンクリートの材料物性を持つ弾性の 2 次元 平面応力要素とし, 柱梁の交点のみで結合する。各階重量は $1150 \mathrm{kN}$ とし, 梁のみに均等分布させる。また, BPY 下部の基礎梁は剛体と する。

BPY モデルの最下層柱脚部には, 図 3(a)に示す 4 枚のウィングを 持つ BPY を配置する注 1)。ウィングの形状・寸法(250x300x25)は, 柱脚浮き上がりに伴って面外曲げを受けるウィングの両端部に塑性 ヒンジラインが形成される時の降伏耐力が鉛直荷重時の平均柱軸方 向力の約 $30 \%$ になるよう設定している。BPY ウィング外側端部は 完全固定とし，BPY 下面と基礎梁の間には接触条件を考慮する。な お, 静的解析によると, BPY は図 3(b)のような柱軸方向力一浮き上 がり変位関係（柱断面図心位置）を示し，この履歴挙動は既往の実 験結果 21, 22) と良い対応を示している。図中の一点鎖線は, 柱軸方向 力を受けてウィングの内外端部に塑性ヒンジが生じる時の降伏耐力 を示す。また, 地震応答解析より得られた BPYの荷重一変形関係 を付録 $\mathrm{A}$ に示す。

部材は鋼で, BPY と 1 階柱は弾塑性材料とし, 移動硬化則を適用 して降伏の判定は有効応力度で行なう。また, BPY 部分では大変形 を考慮する。材料物性值は, ヤング率 $2.06 \times 10^{5} \mathrm{~N} / \mathrm{mm}^{2}, 2$ 次勾配 $2.06 \times 10^{3} \mathrm{~N} / \mathrm{mm}^{2}$, 降伏応力度 $294 \mathrm{~N} / \mathrm{mm}^{2}$, ポアソン比 0.3 , 比重 7.8 とする。2 階以上の柱と梁の梁要素には tri-linear 形の曲げモーメ ントー曲率関係を適用する。

減衰は初期剛性比例型で, 減衰定数は $\mathrm{h}=2 \%$ とする。直接数值積 分には Newmark の $\beta$ 法（ $\beta=1 / 4 ）$ を用いて Newton-Raphson 法の 平衡反復計算を併用する。時間刻夕は $0.01 \mathrm{~s}$ を基本として平衡収束 状態に応じて細かくする。なお, 浮き上がりに伴う柱脚部の着地衝

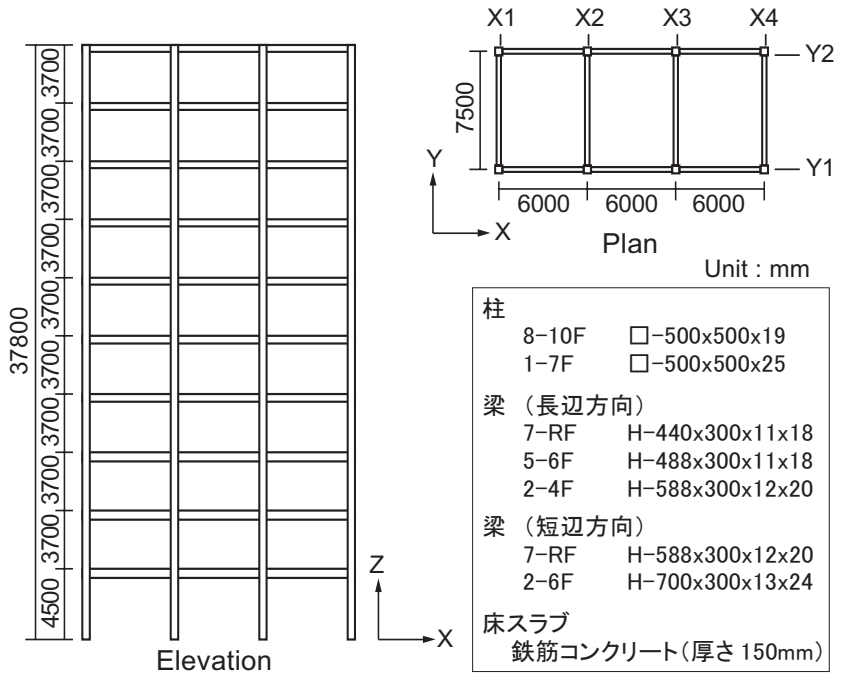

図 1 解析対象鉄骨架構
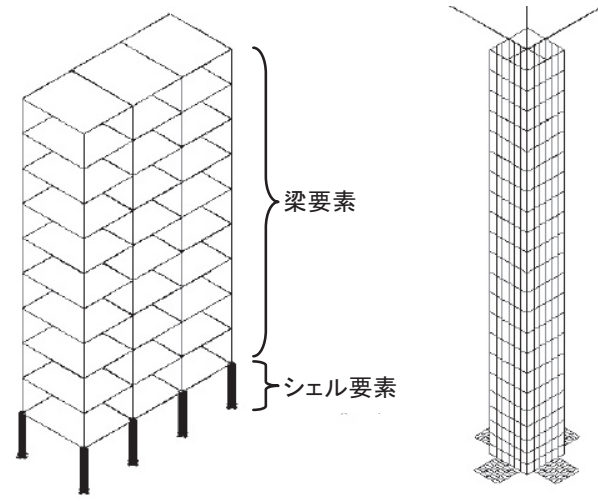

(a) 全体モデル

（b）シェル要素柱モデル

図 2 解析モデル
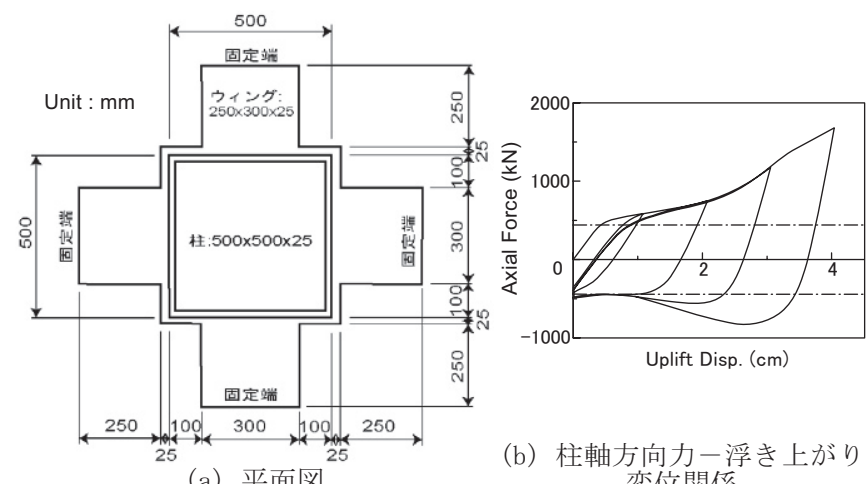

(a) 平面図 変位関係

図 3 浮き上がり降伏ベースプレート

表 1 入力地震動

\begin{tabular}{c|c|c|c}
\hline Seismic Motion & Comp. & PGA $\left(\mathrm{cm} / \mathrm{s}^{2}\right)$ & PGV $(\mathrm{cm} / \mathrm{s})$ \\
\hline Northridge & NS & 971 & 70.9 \\
\cline { 2 - 4 } $\begin{array}{c}1994 \\
\text { Tarzana }\end{array}$ & EW & 1745 & 113.1 \\
\cline { 2 - 4 } & UD & 1028 & 70.1 \\
\hline Hyogo-ken Nanbu & NS & 818 & 91.1 \\
\cline { 2 - 4 } 1995 & EW & 617 & 74.5 \\
\cline { 2 - 4 } JMA Kobe & UD & 332 & 40.3 \\
\hline Tottori-ken Seibu & NS & 911 & 119.5 \\
\cline { 2 - 4 } 2000 & EW & 762 & 85.0 \\
\cline { 2 - 4 } Hino & UD & 778 & 56.4 \\
\hline Niigata-ken Chuetsu & NS & 1142 & 44.3 \\
\cline { 2 - 4 } 2004 & EW & 1676 & 147.6 \\
\cline { 2 - 4 } Kawaguchi & UD & 870 & 69.7 \\
\hline
\end{tabular}


突時の挙動に関しては, 文献 18$) て ゙$ 模型振動台実験より得られた柱軸 方向力を解析と比較検討し, 解析は実験を概ね十分な精度で再現で きることを確認している。

\section{2 入力地震動}

解析に用いる地震動は, 表 1 に示す 4 記録, 寸なわち, 1994 年 ノースリッジ地震の Tarzana, 1995 年兵庫県南部地震の JMA 神戸 (以下 Kobe と呼ぶ), 2000 年鳥取県西部地震の KiK-net 日野(以下 Hino と呼ぶ), 2004 年新潟県中越地震の川口(以下 Kawaguchi と呼 ぶ)である。柱脚浮き上がり構造では, 地震動の上下動成分が応答性 状に影響を及ぼす可能性が考えられるため, 上下動成分のスペクト ル強度 ${ }^{23)}(\mathrm{h}=0.05)$ が $150 \mathrm{~cm}$ 以上となる記録を選定した。各記録の速 度応答スペクトルを図 4 に示す。継続時間は, 解析に要する時間が 膨大になるため, 記録の主要動部分の 20 秒間とする。この継続時 間においては原記録の Arias Intensity ${ }^{24)} の$ 94\%以上が含まれる。

各記録の水平 2 成分を合成した最大水平地動速度はいずれも $100 \mathrm{~cm} / \mathrm{s}$ を超えるが, 本論文では水平 2 成分を合成した最大水平地 動速度を $50 \mathrm{~cm} / \mathrm{s}, 100 \mathrm{~cm} / \mathrm{s}$ に基準化して入力寸る。

入力は, 水平 1 方向, 水平 2 方向同時, 水平 $\cdot$ 上下 3 方向同時の 3 種類とし, 短辺 $(\mathrm{Y})$ 方向に NS 成分を, 長辺 $(\mathrm{X})$ 方向に $\mathrm{EW}$ 成分を 作用させる。
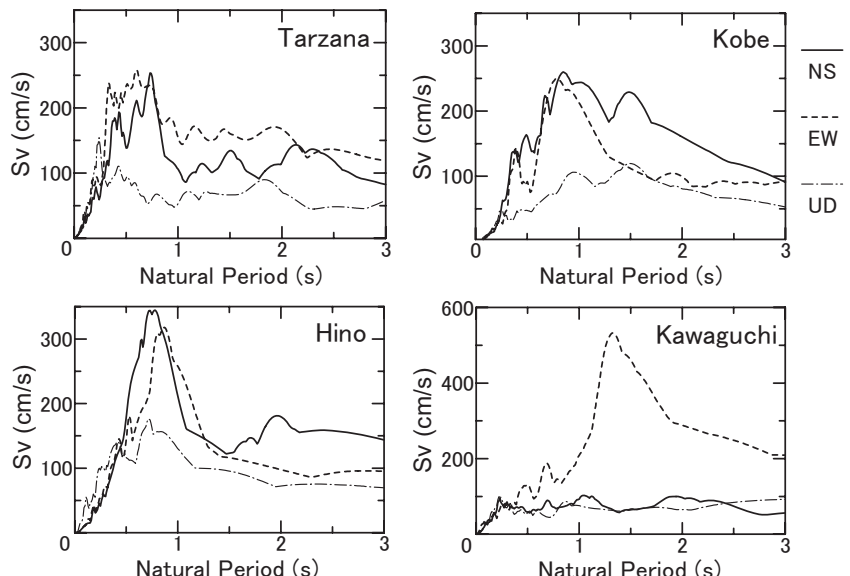

図 4 速度応答スペクトル $(\mathrm{h}=0.05)$

\section{3. 静的荷重増分解析結果}

柱脚固定(FIX)モデルと柱脚浮き上がり(BPY)モデルについて, 層 せん断力係数分布を $A i$ 分布とした静的荷重増分解析により得られ た基部転倒モーメントと頂部水平変位（屋上階重心位置，以下同じ） の関係を図 5 に示す。図中の一点鎖線は, BPY モデルの短辺方向に おいて, 片側構面の 4 本の柱の BPY が降伏耐力に達する時の転倒 モーメントである。頂部水平変形角 $1 / 100$ の時の架構のベースシア 係数は, FIX モデルで短辺方向 0.41 , 長辺方向 0.37 であり, BPY モデルで短辺方向 0.27 , 長辺方向 0.30 である。また, 短辺方向に おいて, BPY が無く柱脚が単純に浮き上がる時のベースシア係数は 0.13 , BPY が浮き上がり降伏する時のベースシア係数は 0.18 であ る。短辺方向では, 降伏後も耐力の上昇が続くという BPY の柱軸 方向力ー浮き上がり変位関係（図 3(b)参照）の特徴が現れ, 柱脚部 が浮き上がって BPY が降伏耐力に達すると転倒モーメントはほぼ 頭打ちとなるが，その後の耐力上昇は比較的大きい。

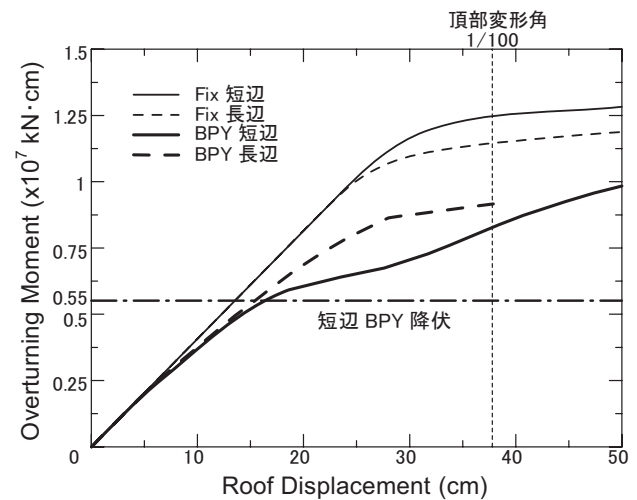

図 5 基部転倒モーメントー頂部水平変位関係(静的荷重増分解析)

\section{4. 地震応答解析結果と考察}

\section{1 固有周期}

架構の固有周期は, FIX モデルで 1 次 $1.26 \mathrm{~s}$ (長辺), 2 次 $1.25 \mathrm{~s}$ (短 辺), 3 次 $1.04 \mathrm{~s}$ (据れ), BPY モデルで 1 次 $1.62 \mathrm{~s}$ (短辺), 2 次 $1.42 \mathrm{~s}$ (長 辺)，3 次 $1.20 \mathrm{~s}$ (㧖れ)である。FIX モデルに対する BPY モデルの 1 次固有周期の比は，短辺方向 1.30 , 長辺方向 1.13 である。

\section{2 基部転倒モーメントと頂部水平変位の関係}

Tarzana $(100 \mathrm{~cm} / \mathrm{s}$, 水平・上下 3 方向之水平 2 方向)入力時の FIX モデルと BPY モデルの基部における転倒モーメントと頂部水平変 位の関係を図 6 に示寸。図中の破線は層せん断力係数分布を $A i$ 分
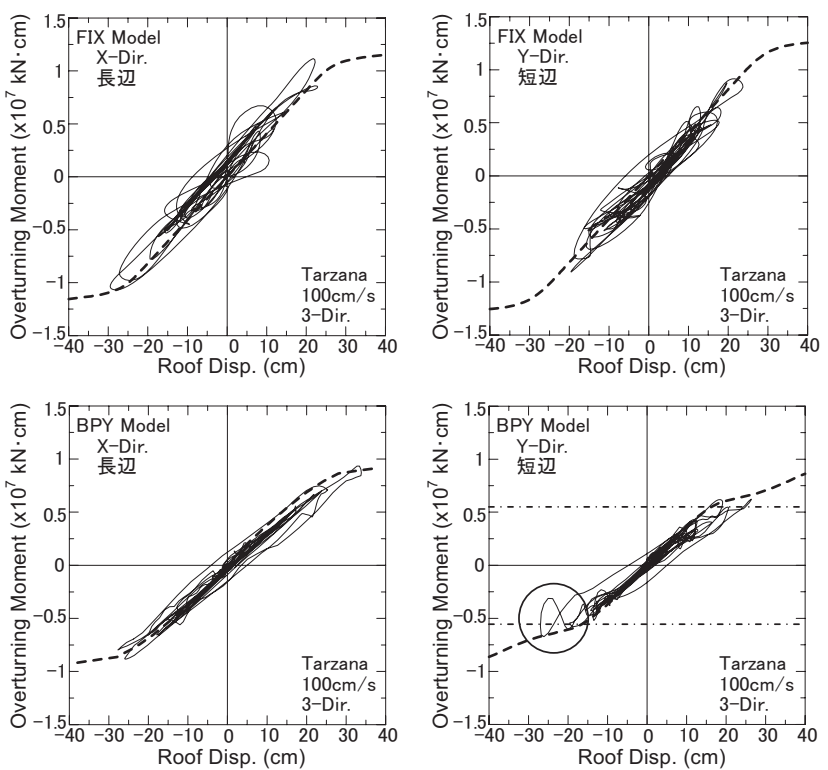

(a) 水平・上下 3 方向入力 (Tarzana, $100 \mathrm{~cm} / \mathrm{s}$ )
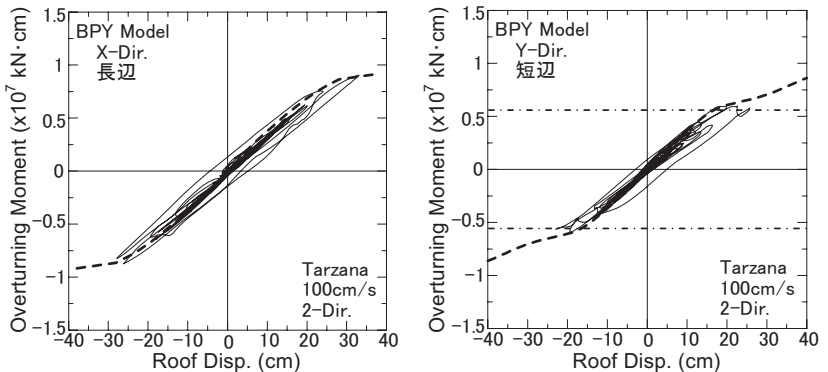

(b) 水平 2 方向入力（Tarzana, $100 \mathrm{~cm} / \mathrm{s}$ )

図 6 基部における転倒モーメントと頂部水平変位の関係 
布とした静的荷重増分解析の結果を示し, 一点鎖線は BPY モデル 短辺方向における BPY浮き上がり降伏時の転倒モーメントを表す。 BPY モデルと FIX モデルともに地震応答解析結果は静的荷重増分 解析結果と良く一致し, BPY モデルの短辺方向では浮き上がり降伏 時に転倒モーメントがほぼ頭打ちとなる傾向を示す。また, FIX モ デルでは全体として安定した履歴挙動を示すのに対して, BPY モデ ルでは既往の研究 4), 5), 25), 26)で指摘されているように浮き上がり振 動中に柱脚固定時とは異なる高次モード振動の影響が若干現れてい る。一方, 図 6(a) と(b)を比較すると, BPY モデル短辺方向では, 図中○印箇所に上下動による影響が見られる。

なお，他の地震動入力時の結果も同様であった。

\section{3 変位とベースシア係数の時刻歴応答}

図 7 に Tarzana $(100 \mathrm{~cm} / \mathrm{s}, 3$ 方向)入力時の BPY モデル隅柱の浮 き上がり変位（柱断面図心位置）時刻歴を示す。 8 11 秒の間では $\mathrm{X} 4 \mathrm{Y} 2$ 位置の柱脚から反時計回りに順に浮き上がり，11 秒以降は対 角線上の柱脚(X1Y2 と X4Y1)が交互に浮き上がりを繰り返している。 このような挙動は, 平面架構モデルの応答では現れず, 多方向入力 を受ける立体架構モデル特有の応答である。図 8(a)の頂部水平変位 の軌跡もこの挙動に対応していることが確認できる。一方, $\operatorname{Kobe}(100 \mathrm{~cm} / \mathrm{s}, 3$ 方向 $)$ 入力時の頂部水平変位の軌跡には, 図 8(b) のように方向性が強く表れており, 短辺方向の応答では同一構面の 柱脚がほぼ同時に浮き上がる挙動を示す。

図 9 は Tarzana と Kobe(各々 $100 \mathrm{~cm} / \mathrm{s}, 3$ 方向)入力時の FIX モデ ルと BPY モデルの頂部水平変位時刻歴で, 短辺方向の細実線は隅 柱以外の柱脚部の浮き上がりから計算した架構の剛体回転成分 $\theta$ (図 10(a)参照) を除いた值を示す。BPY モデル短辺方向の最大応 答時には, 架構の剛体回転による変位が占める割合が比較的大きく, また, BPY モデルでは浮き上がり後の応答周期が伸びていることが 確認できる。他の結果も同様であった。

図 11 は Tarzana $(100 \mathrm{~cm} / \mathrm{s}, 2$ 方向と 3 方向)入力時の FIX モデル と BPY モデルの短辺方向のベースシア係数の時刻歴であり, 1 点鎖 線は BPY が降伏耐力に達する時のベースシア係数を表す。BPY モ デルでは, BPY 降伏耐力時にベースシア係数がほぼ頭打ちになる。 また, BPY モデルの応答に見られる浮き上がりに伴う短周期の振動 が, 水平 2 方向入力時よりも水平・上下 3 方向入力時に多く現れて いることから，上下動の影響と考えられる。他の地震動入力時の結 果も同様であった。
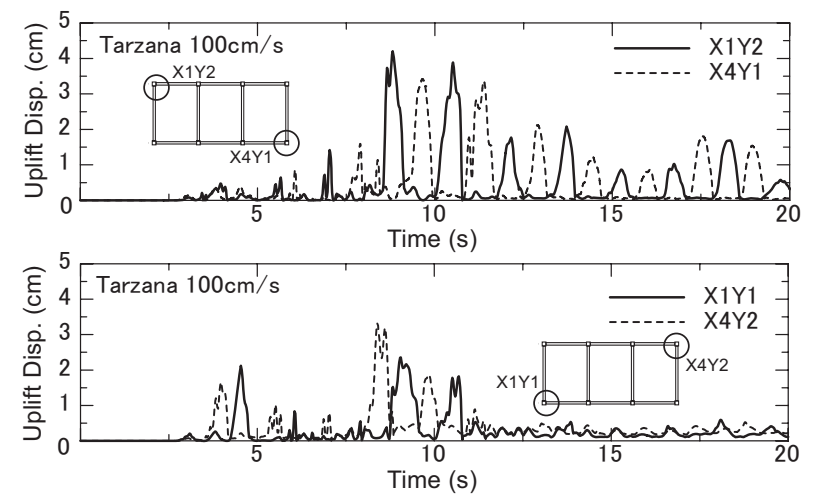

図 7 柱脚部浮き上がり変位時刻歴 (Tarzana, $100 \mathrm{~cm} / \mathrm{s}, 3$ 方向)

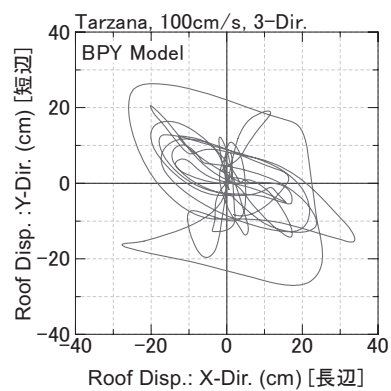

(a) Tarzana

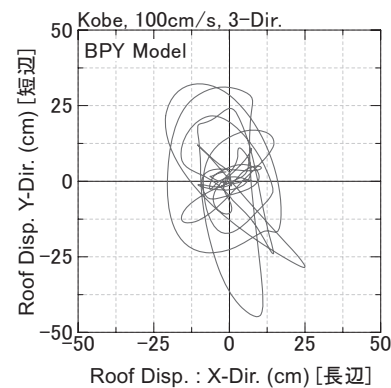

(b) Kobe
図 8 屋上階重心位置の水平変位軌跡 $(100 \mathrm{~cm} / \mathrm{s}, 3$ 方向 $)$
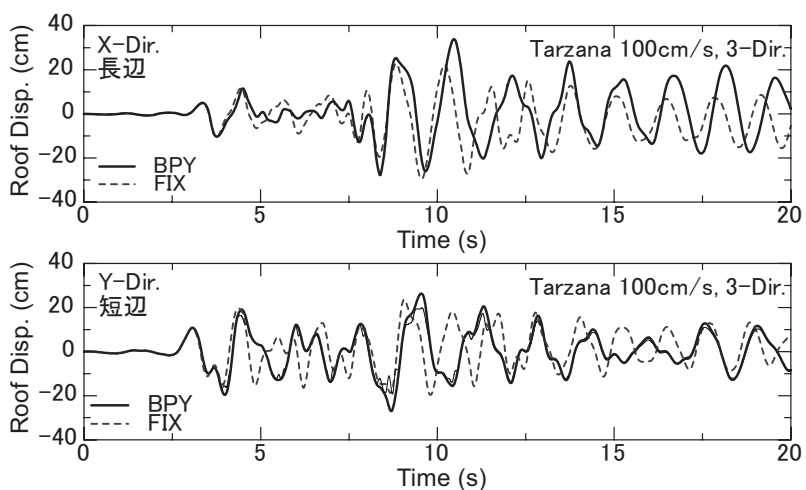

(a) Tarzana

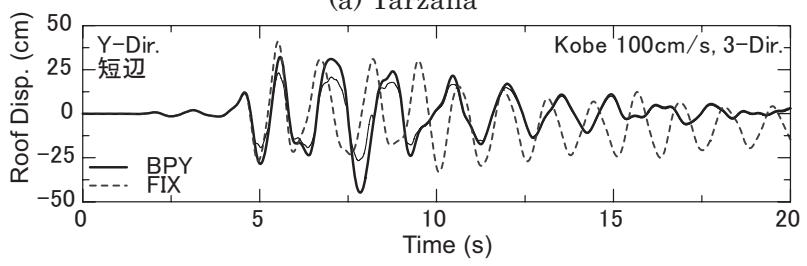

(b) Kobe

図 9 頂部水平変位時刻歴 $(100 \mathrm{~cm} / \mathrm{s}, 3$ 方向 $)$
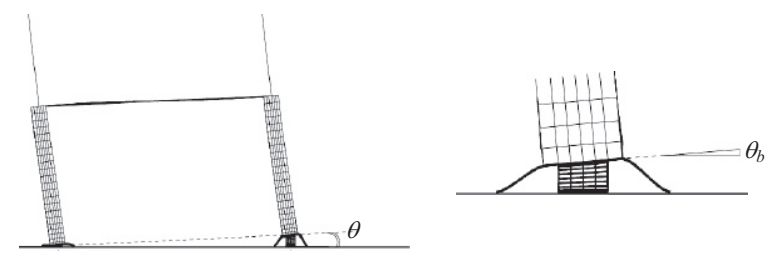

(a) 架構短辺方向の剛体回転 $\theta$

(b) 最下層柱脚部の回転 $\theta_{b}$ 図 10 架構の剛体回転と最下層柱脚部の回転

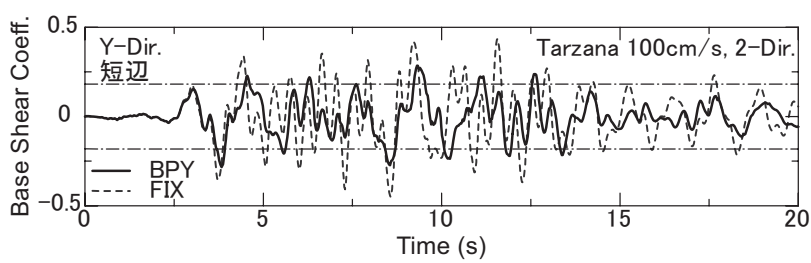

(a) 水平 2 方向入力

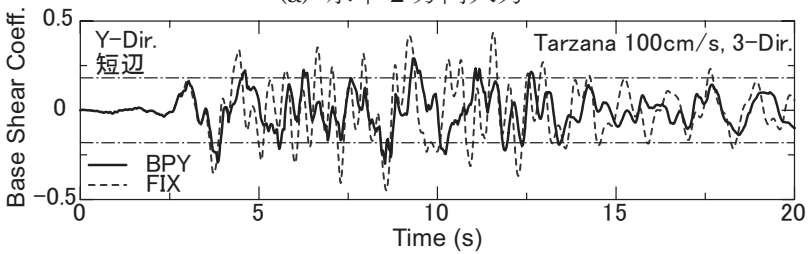

(b) 水平 $\cdot$ 上下 3 方向入力

図 11 ベースシア係数時刻歴（Tarzana, $100 \mathrm{~cm} / \mathrm{s}, 3$ 方向） 


\section{4 最大層間変形角および最大層せん断力の高さ方向分布}

図 $12(\mathrm{a})$ は, $\mathrm{Hino}(50 \mathrm{~cm} / \mathrm{s}$ と $100 \mathrm{~cm} / \mathrm{s} ， 3$ 方向)入力時の最大層間 変形角の高さ方向分布である。長辺，短辺方向とも，3 層以上では BPY モデルの方が FIX モデルよりも概初小さくなるが， 1 層では FIX モデルよりも BPY モデルの方が大きくなる。図中 $\times$ 印は架構 の剛体回転成分 $\theta$ (図 10(a)参照) を除いた $100 \mathrm{~cm} / \mathrm{s}$ 入力時の $\mathrm{BPY}$ モデル短辺方向の最大層間変形角であり, 浮き上がりによる架構の 剛体回転成分が大きくなることで上部構造自体の変形が抑制される ことが分かる。しかし, 浮き上がりによる剛体回転成分を除いても， 1 層での最大層間変形角は FIX モデルよりも大きい。これは, 他の 地震動入力時でも同様で, BPY モデルの 1 層では柱脚部の回転に対 寸る固定度が小さくなり，図 $10(\mathrm{~b})$ に示すような柱脚部の回転量 $\theta_{b}$ が大きくなるためである。ここで, Tarzana および Kobe(各々 $100 \mathrm{~cm} / \mathrm{s}, 3$ 方向)入力時の BPY モデル短辺方向 1 層において, 層 間変形角から 1 層柱脚部の回転角 $\theta_{b}$ を除いた層間変形角成分の時刻
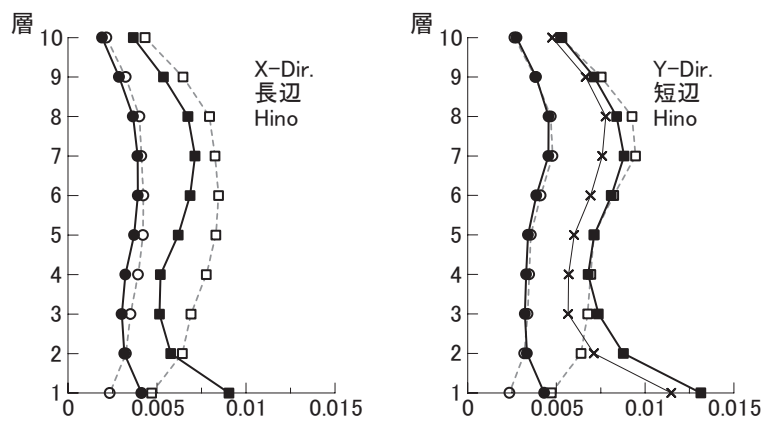

（a）最大層間変形角（rad.）
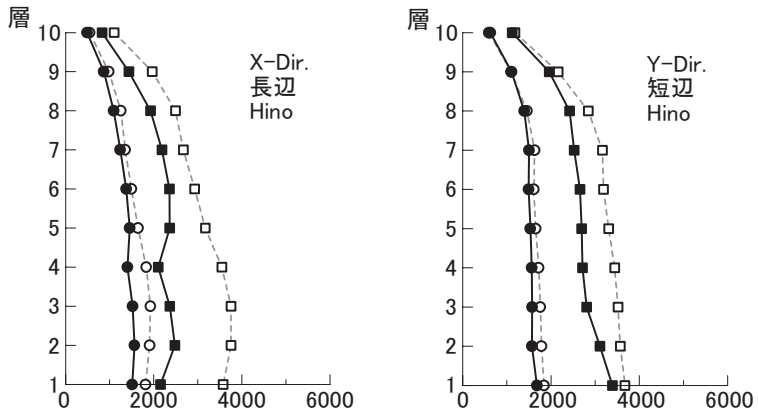

(b) 最大層せん断力 $(\mathrm{kN})$

-o-- FIX $50 \mathrm{~cm} / \mathrm{s}, \quad--\square--$ FIX $100 \mathrm{~cm} / \mathrm{s}$

$\rightarrow$ BPY $50 \mathrm{~cm} / \mathrm{s}, \rightarrow$ BPY $100 \mathrm{~cm} / \mathrm{s}, \longrightarrow$ 剛体回転成分無 $100 \mathrm{~cm} / \mathrm{s}$

図 12 最大応答值の高さ方向分布 (Hino)

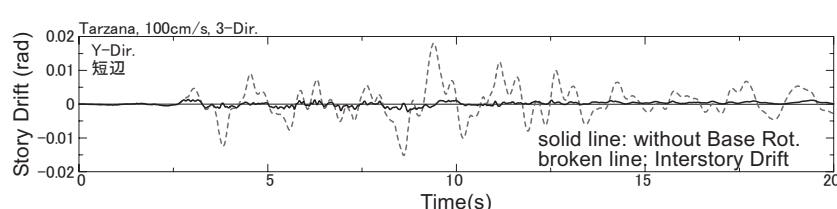

(a) Tarzana $(100 \mathrm{~cm} / \mathrm{s}, 3$ 方向 $)$

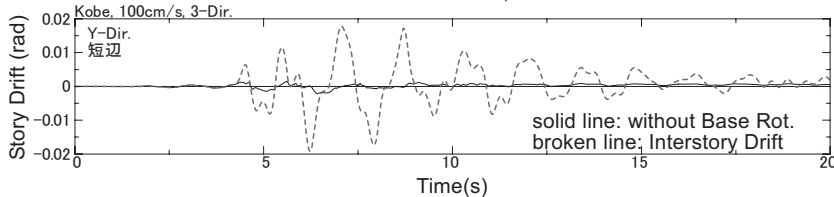

(b) Kobe $(100 \mathrm{~cm} / \mathrm{s}, 3$ 方向)

図 $13 \mathrm{BPY}$ モデル短辺方向最下層の層間変形角と柱脚回転の影響
歴を図 13 の実線で示し，1 層の層間変形角を破線で示す。なお，こ の際の柱脚部回転角 $\theta_{b}$ は建物内側各柱 $(\mathrm{X} 2$ および $\mathrm{X} 3$ 通り)の柱脚部 回転角の平均とした。この図より，1 層の層間変形角の殆どが柱脚 の回転によって生じており，1 層の柱自体の変形を比べると，FIX モデルより BPY モデルの方が小さいことが分かる。

図 $12(\mathrm{~b})$ は, $\operatorname{Hino}(50 \mathrm{~cm} / \mathrm{s}$ と $100 \mathrm{~cm} / \mathrm{s}, 3$ 方向)入力時の最大層せ 几断力の高さ方向分布である。最大層せん断力は，長辺，短辺方向 とも全層にわたって BPY モデルの方が FIX モデルよりも小さくな る。下層になるほど BPY モデルと FIX モデルの差は広がる傾向に あり，また，入力レベルが大きいほど両モデルの差は大きくなる。 他の地震動入力の結果もほぼ同様であった。

上述したように，BPY モデルでは，柱脚部の回転に対する固定度 が小さくなるため, 最下層の層間変形角は FIX モデルよりも増大寸 るが，このような地震応答時の特徴は，露出型柱脚を有する鉄骨造
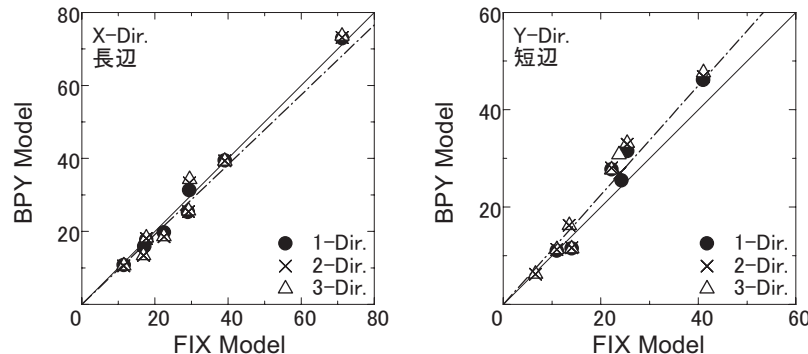

（a）最大頂部水平変位 $(\mathrm{cm})$
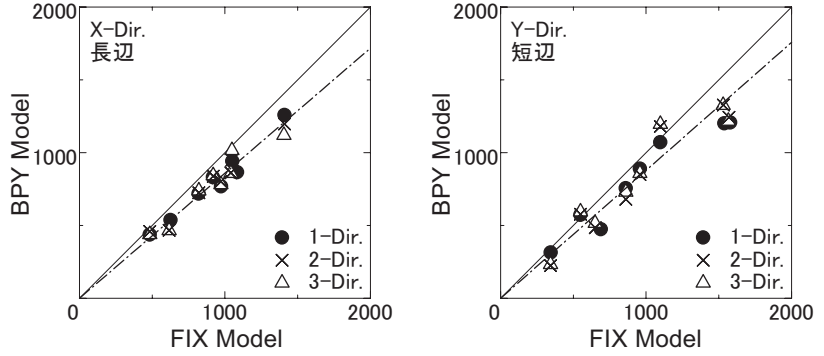

（b）最大頂部水平加速度 $\left(\mathrm{cm} / \mathrm{s}^{2}\right)$
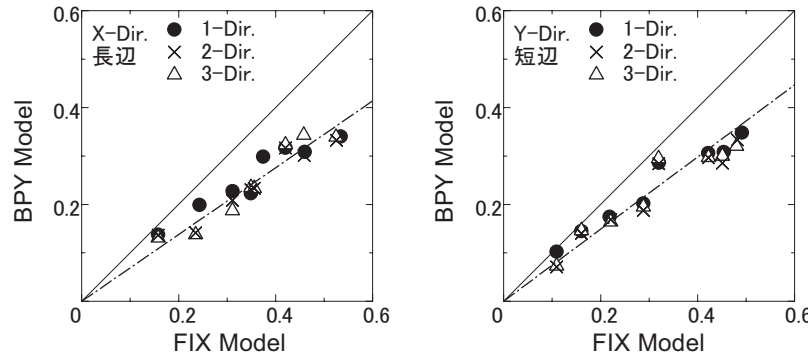

(c) 最大ベースシア係数

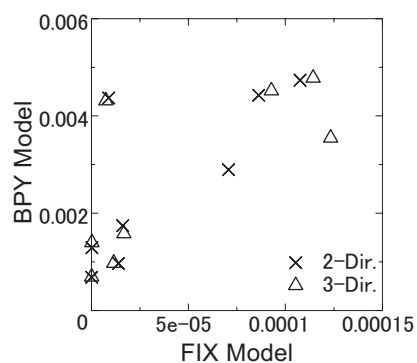

（d）屋上階の最大㨭れ回転角（rad $)$

図 14 FIX モデルと BPY モデルの最大応答值比較 
多層骨組に関する既往の研究 27) 30) でも指摘されており, BPY モデ ルの応答においてもこれと同様な特徵を示寸ものと考えられる。

\section{5 最大応答值の比較}

図 14(a)〜(d)には，横軸に FIX モデル，縦軸に BPY モデルの方 向毎の最大応答值を示す。図には, 水平 1 方向, 水平 2 方向, 水平 上下 3 方向の場合と最大水平地動速度 $50 \mathrm{~cm} / \mathrm{s}, 100 \mathrm{~cm} / \mathrm{s}$ の全ての場 合が含まれている。1 点鎖線は両モデルの相関関係を表し, 実線は FIX モデルと BPY モデルの比が 1 の場合を表す。

図 14(a)に示す頂部水平変位は, 長辺方向では BPY モデルと FIX モデルはほぼ等しく(平均 BPY/FIX=0.96), 短辺方向では BPY モデ

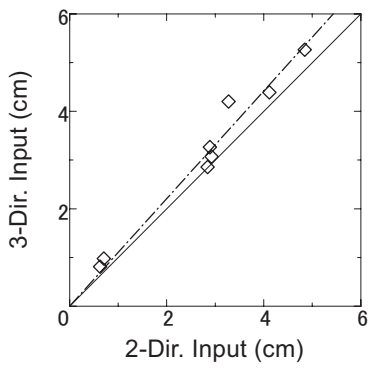

図 15 上下動の有無による最大浮き上がり変位比較

表 2 柱脚部の最大浮き上がり変位 $(\mathrm{cm})$

\begin{tabular}{|c|c|c|c|c|c|c|c|c|}
\hline & \multicolumn{2}{|c|}{ Tarzana } & \multicolumn{2}{|c|}{ Kobe } & \multicolumn{2}{|c|}{ Hino } & \multicolumn{2}{|c|}{ Kawaguchi } \\
\hline & $50 \mathrm{~cm} / \mathrm{s}$ & $100 \mathrm{~cm} / \mathrm{s}$ & $50 \mathrm{~cm} / \mathrm{s}$ & $100 \mathrm{~cm} / \mathrm{s}$ & $50 \mathrm{~cm} / \mathrm{s}$ & $100 \mathrm{~cm} / \mathrm{s}$ & & $100 \mathrm{~cm} /$ \\
\hline X-Dir. & 0.4 & 2.0 & \begin{tabular}{|l|}
0.3 \\
\end{tabular} & 1.3 & \begin{tabular}{|l|}
0.1 \\
\end{tabular} & 0.6 & 2.7 & \\
\hline Y-Dir. & & & & & & & & \\
\hline 2-Dir. & & $\begin{array}{r}3.3 \\
(0.8 \\
\end{array}$ & & & \begin{tabular}{|c|}
0.6 \\
$(2.74)$ \\
\end{tabular} & & \begin{tabular}{|c|}
2.8 \\
$(1.02)$ \\
\end{tabular} & \\
\hline 3-Dir. & $\begin{array}{c}1.0 \\
(1.58) \\
\end{array}$ & $\begin{array}{c}4.2 \\
(1.11) \\
\end{array}$ & $\begin{array}{c}3.1 \\
(1.08) \\
\end{array}$ & $\begin{array}{c}5.3 \\
(0.94) \\
\end{array}$ & \begin{tabular}{|c|}
0.8 \\
$(3.52)$ \\
\end{tabular} & \begin{tabular}{|c|}
3.3 \\
$(1.19)$ \\
\end{tabular} & \begin{tabular}{|c|}
2.9 \\
$(1.03)$ \\
\end{tabular} & $\begin{array}{c}4.4 \\
(1.11) \\
\end{array}$ \\
\hline
\end{tabular}

注）（）内の数字は次式の比を表す。

(多方向入力の最大值) / (短辺及び長辺 1 方向入力の最大値の和)
ルの方がやや大きくなる(平均 BPY/FIX=1.12)。図 14(b)に示寸頂部 水平加速度では, 長辺方向 (平均 $\mathrm{BPY} / \mathrm{FIX}=0.86$ ), 短辺方向 (平均 BPY/FIX=0.88) ともに BPY モデルの方が FIX モデルよりやや小さ い。図 14(c)に示すべースシア係数は, 長辺方向(平均 BPY/FIX=0.69), 短辺方向(平均 BPY/FIX=0.74) ともに BPY モデルの方がかなり小さ くなる。

上下動成分の影響を検討するために，水平 2 方向 $(2 \mathrm{D})$ 入力に対す る水平・上下 3 方向 $(3 \mathrm{D})$ 入力の最大応答值の比をとると, 頂部水平 変位で 0.99-1.14(平均 3D/2D=1.01), 頂部水平加速度で 0.94-1.07 $(3 \mathrm{D} / 2 \mathrm{D}=1.01)$, ベースシア係数で $0.94-1.14(3 \mathrm{D} / 2 \mathrm{D}=1.01)$ であり， 水平方向の応答には上下動成分は殆ど影響していない。

図 14(d)に示す屋上階の最大㨭れ回転角は，FIX モデルでは Kawaguchi $(100 \mathrm{~cm} / \mathrm{s}, 3$ 方向)入力時に最大 0.00012 であるが, BPY モデルでは Kobe $(100 \mathrm{~cm} / \mathrm{s}, 3$ 方向)入力時に最大 0.0048 まで増加し ている。㨭れ応答には両モデルの差異が大きく現れており, 設計の 際にはこの点に留意する必要がある。

図 15 には, 横軸を水平 2 方向入力時, 縦軸を水平・上下 3 方向 入力時のそれぞれ BPY モデル 1 層柱脚部に生じる最大浮き上がり 変位を示す。 2 方向入力に対する 3 方向入力の比は 1.01-1.38(平均 $3 \mathrm{D} / 2 \mathrm{D}=1.16)$ であり, 最大浮き上がり変位は上下動の影響により平 均で $15 \%$ 程度増加する。

各地震動に対する最大浮き上がり変位を表 2 に示す。表中の最大 值は Kobe $(100 \mathrm{~cm} / \mathrm{s} ， 3$ 方向 $)$ 入力時の $5.3 \mathrm{~cm}$ であり，短辺方向スパ ン長の約 $1 / 140$ である。ここで, 水平 1 方向入力で浮き上がり変位 が小さい Tarzana $50 \mathrm{~cm} / \mathrm{s}$, Hino $50 \mathrm{~cm} / \mathrm{s}$ を除くと, 水平 1 方向入 力時の短辺および長辺方向の最大浮き上がり変位の和に対する多方 向入力時の比は, 2 方入力の場合 0.87-1.05(平均 0.98), 3 方向入力 の場合 0.94-1.19(平均 1.08) で, 概水 1 程度の值となり, 水平 1 方向 入力の応答から多方向入力の応答を予測できる可能性を示唆してい

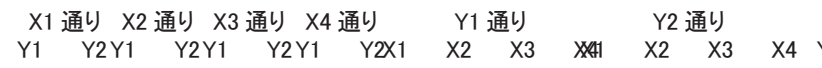

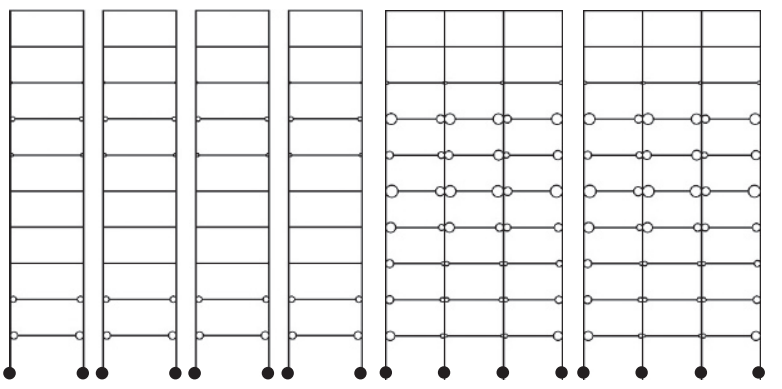

FIX Model (Tarzana)

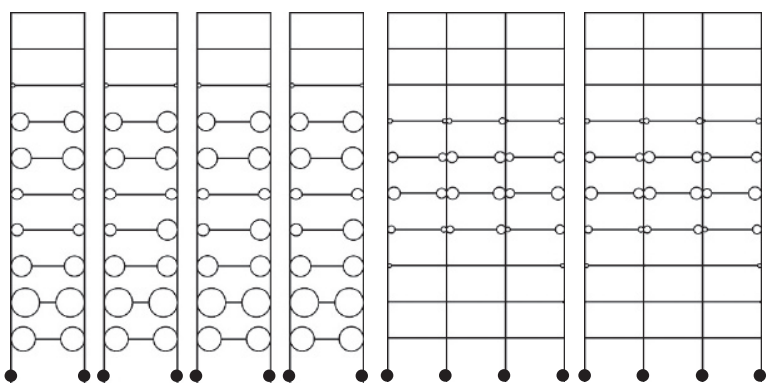

FIX Model (Kobe)
$X 1$ 通り X2 通り X3 通り X4 通り Y1 通り $\begin{array}{llllllllll}Y 2 Y 1 & Y 2 Y 1 & Y 2 Y 1 & Y 2 X 1 & X 2 & X 3 & X 41 & X 2 & X 3 & X 4\end{array}$
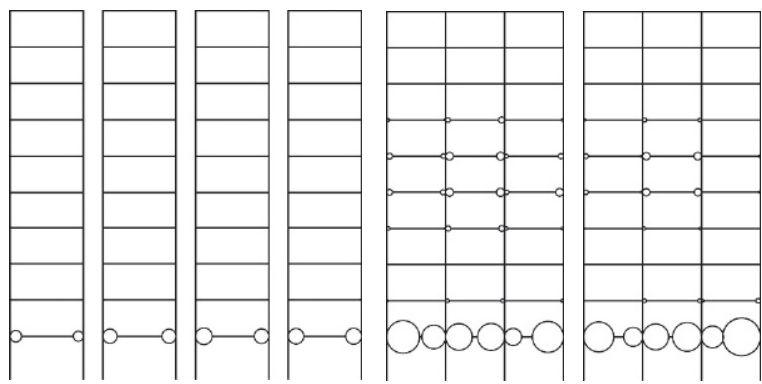

BPY Model (Tarzana)
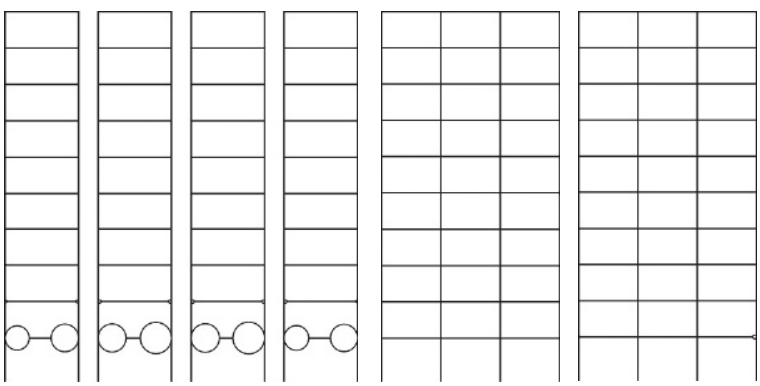

BPY Model (Kobe)
5

$\stackrel{\circ}{10}$

20

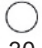

30

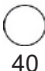

40

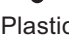

Hinge

図 16 梁の最大累積塑性曲率倍率 
表 3 ベースプレートの最大累積塑性歪倍率

\begin{tabular}{|c|c|c|c|c|c|c|c|c|}
\hline & \multicolumn{2}{|c|}{ Tarzana } & \multicolumn{2}{|c|}{ Kobe } & \multicolumn{2}{|c|}{ Hino } & \multicolumn{2}{|c|}{ Kawaguchi } \\
\hline & $50 \mathrm{~cm} / \mathrm{s}$ & $100 \mathrm{~cm} / \mathrm{s}$ & $50 \mathrm{~cm} / \mathrm{s}$ & $100 \mathrm{~cm} / \mathrm{s}$ & $50 \mathrm{~cm} / \mathrm{s}$ & $100 \mathrm{~cm} / \mathrm{s}$ & $50 \mathrm{~cm} / \mathrm{s}$ & $100 \mathrm{~cm} / \mathrm{s}$ \\
\hline \multirow{2}{*}{ 1-Dir $\frac{\mathrm{X}-\mathrm{Di}}{\mathrm{Y}-\mathrm{Di}}$} & 16.5 & 126 & 4.3 & 129 & 0.5 & 18.1 & 253 & 384 \\
\hline & 5.3 & 129 & 155 & 267 & 0.7 & 166 & 0 & 7.3 \\
\hline 2-Dir. & 32.4 & 334 & 224 & 411 & 16.3 & 287 & 261 & 475 \\
\hline 3-Dir. & 41.2 & 480 & 244 & 427 & 16.6 & 308 & 258 & 469 \\
\hline $2 \mathrm{D} / 1 \mathrm{D}$ & 1.49 & 1.31 & 1.45 & 1.04 & - & 1.56 & 1.03 & 1.21 \\
\hline $3 \mathrm{D} / 2 \mathrm{D}$ & 1.27 & 1.44 & 1.09 & 1.04 & 1.02 & 1.07 & 0.99 & 0.99 \\
\hline
\end{tabular}

注） $2 \mathrm{D} / 1 \mathrm{D}, 3 \mathrm{D} / 2 \mathrm{D}$ の数字は次式の比を表す。

$2 \mathrm{D} / 1 \mathrm{D}=(2$ 方向入力の最大值 $) /($ 短辺及び長辺 1 方向入力の最大值の和 $)$ $3 \mathrm{D} / 2 \mathrm{D}=(3$ 方向入力の最大值 $) /(2$ 方向入力の最大值 $)$

る。ただし，この浮き上がり変位比は，上下動の影響を受けて，3 方向入力の方が 2 方向入力よりも平均で $10 \%$ ぼ゙大きくなる。

\section{6 梁端と降伏ベースプレートの塑性変形量}

Tarzana と Kobe $(100 \mathrm{~cm} / \mathrm{s} ， 3$ 方向)入力時の FIX モデルと BPY モデルの梁端における累積塑性曲率倍率（梁端の降伏曲率に対寸る 累積塑性曲率の比，累積塑性曲率は正側と負側の累積塑性曲率の絶 対值和）を図 16 に示寸。FIX モデルでは, 短辺, 長辺方向ともに 2 〜8 階の梁端で降伏している。一方，BPY モデルでは，長辺方向の 5〜8 階でも多少降伏しているものの主に 2 階梁端に塑性変形が集 中し，そこでの累積塑性曲率倍率は FIX モデルよりも大きくなる。 これは, BPY モデル最下層の層間変形角が FIX モデルよりも大き くなることに関係している。露出型柱脚を有する鉄骨造多層骨組に 関する既往の研究 27) 30)でも, 柱脚が降伏すると柱脚固定の場合に 比べて 1 層柱頭あるいは 2 階梁端の損傷が増加することが指摘され ており, BPY モデルでもこれと同様な傾向が現れているものと考え られる。

BPY モデルの BPY ウィングに生じる軸方向の累積塑性歪倍率 （降伏歪に対する累積塑性歪の比）を表 3 に示す。最大值が生じる 箇所はウィングの柱側端部であり, BPY 柱脚の静加力実験結果 ${ }^{22)}$ とも整合している。表 3 に示寸ように, 水平 1 方向入力で浮き上が り変位が小さい Hino $50 \mathrm{~cm} / \mathrm{s}$ を除くと, 水平 1 方向入力時の短辺お よび長辺方向の累積塑性歪倍率の和に対寸る水平 2 方向入力時の比 (2D/1D)は 1.03-1.56(平均 1.30)であり 1 以上の值となる。多方向入 力時には柱脚部の浮き上がり変位が水平 1 方向入力時よりも増すた めに, 累積塑性歪倍率も増大寸ると考えられる。2 方向入力に対す る 3 方向入力の比(3D/2D)は, Tarzana 入力では 1.27-1.44 で上下動 の影響を大きく受けるが, それ以外の入力では 0.99-1.09(平均 1.03) で, 上下動の影響は小さい。また, BPY 柱脚の静加力実大実験結果 22)によると, 最大累積塑性歪倍率は 410１280 まで見込めることが 報告されており, 本解析で得られた BPY の最大累積塑性歪倍率は 概初推定される終局限界值の範囲にあると考えられる。

\section{5. 結論}

浮き上がりに伴って降伏するベースプレートを最下層柱脚部に組 み込んだ 10 層鉄骨架構を対象とし, 柱脚固定(FIX)モデルと最下層 柱脚部に降伏ベースプレートを組み込んだ降伏ベースプレート (BPY)モデルの 2 種類の立体架構モデルについて, 水平 1 方向, 水 平 2 方向同時，水平・上下 3 方向同時の地震動を入力した場合の 3 次元有限要素法による弾塑性地震応答解析を行い, その応答性状を 検討した。得られた主な結論は以下の通りである。
1）柱脚部に浮き上がり降伏ベースプレートを組み込むことで, 水 平 2 方向同時, 水平・上下 3 方向同時の地震動を入力した場合にお いても, 平面架構と同様に立体架構のベースシアと基部転倒モーメ ントが頭打ちとなる傾向を示す。また, BPY モデルの地震応答解析 結果は, 水平 1 方向載荷時の静的荷重増分解析結果と良く一致する。

2) 立体架構においても平面架構と同様に最大層せん断力は, 全層 にわたって BPY モデルの方が FIX モデルよりも小さくなる。

3）柱脚浮き上がりによって架構の剛体回転成分が生じることで 上部構造自体の変形が抑制されるため, 3 層以上の最大層間変形角 は, BPY モデルの方が FIX モデルよりも概ね小さくなる。しかし， BPY モデルでは，柱脚部の回転に対する固定度が小さくなるため, 最下層の層間変形角は FIX モデルよりも増大寸る。柱脚浮き上がり 構造の設計に際しては，この点を考慮する必要がある。

4) 水平 1 方向, 水平 2 方向同時, 水平 $\cdot$ 上下 3 方向同時入力時 の全ての場合において, BPY モデルの最大応答值は, FIX モデルに 比べると, 平均で, 頂部水平変位は $10 \%$ 程度増加し, ベースシア係 数は $25-30 \%$ 程度, 頂部水平加速度は 10 数\%減少する。

5）BPY モデルにおいて, 頂部水平変位, 頂部水平加速度, ベー スシアなどの水平方向の最大応答值には, 地震動の上下動成分は殆 ど影響しない。一方，柱脚部の最大浮き上がり変位は，地震動の上 下動成分の影響を受けて平均で $15 \%$ 程度増加する。また，水平 2 方 向同時, 水平・上下 3 方向同時入力時における屋上階の最大据れ回 転角を見ると，FIX モデルに比べて BPY モデルの方がかなり大き な捩れ応答を生じており，柱脚浮き上がり構造の設計の際にはこの 点に留意する必要がある。

6) FIX モデルでは, 短辺, 長辺方向ともに $2 \sim 8$ 階の梁端が降伏 するのに対して, BPY モデルでは, 梁端の降伏範囲が減少するもの の，上記 3)に関係して，2 階梁端に塑性変形が集中する。

7） BPY モデルの立体振動では，Tarzana 水平・上下 3 方向同時 入力時のように, 或る構面の柱脚部が同時には浮き上がらないこと がある。このように, 入力地震動の特性によっては, 平面モデルで は表れない応答が立体モデルで生じることがある。

本論文では, 地震動による全体入力エネルギーと履歴エネルギー, 位置エネルギーなどの関係を検討していないが，エネルギー応答に 関する検討は今後の課題である。また，露出型柱脚の地震時弾塑性 挙動に関する既往の研究で指摘されている特徵, 即ち, 柱脚固定の 場合に比べて 1 層の最大層間変形角および 2 階梁端の損傷が増加す る現象が, 本研究対象の柱脚浮き上がり構造でも見られた。これら の点も今後の検討課題である。

\section{謝辞}

本研究の一部は, 日本学術振興会科学研究費補助金(19360244, $18560572 ， 19560590)$ 並びに(社)日本鉄鋼連盟「2008 年度鋼構造研 究・教育助成事業」の助成を得た。また, (独)防災科学技術研究所 が運用している KiK-net データを利用した。査読者からは貴重な意 見を頂いた。ここに謝意を表する。

\section{参考文献}

1) Housner, G. W.: The behavior of inverted pendulum structures during earthquakes, Bulletin of the Seismological Society of America, Vol. 53, No. 2, pp. 403-417, 1963.2 
2) Rutenberg, A., Jennings, P. C. and Housner, G. W.: The response of Veterans Hospital Building 41 in the San Fernando earthquake, Earthquake Engineering and Structural Dynamics, Vol. 10, No. 3, pp. 359-379, 1982

3）林康裕: 直接基礎構造物の浮上りによる地震被害低減効果, 日本建築学会 構造系論文集，第 485 号，pp. 53-62，1996.7

4) Meek, J. W.: Effect of foundation tipping on dynamic response, Journal of the Structural Division, ASCE, Vol. 101, No. ST7, pp. 1297-1311, 1975.7

5) Meek, J. W.: Dynamic response of tipping core buildings, Earthquake Engineering and Structural Dynamics, Vol. 6, No. 5, pp. 437-454, 1978

6) Chopra, A. K. and Yim, S. C.-S.: Simplified analysis of structures with foundation uplift, Journal of Structural Engineering, ASCE, Vol. 111, No. 4, pp. 906-930, 1985.4

7) Yim, S. C.-S. and Chopra, A. K.: Simplified earthquake analysis of multistory structures with foundation uplift, Journal of Structural Engineering, ASCE, Vol. 111, No. 12, pp. 2708-2731, 1985.12

8）小堀鐸二, 南井良一郎：地震に依る構造物の非線型振動に就いて（その 4 : 角柱の転倒とロッキング), 日本建築学会論文報告集, 第 54 号, pp. 405-408, 1956.9

9) Oliveto, G., Calio, I. and Greco, A.: Large displacement behavior of a structural model with foundation uplift under impulsive and earthquake excitations, Earthquake Engineering and Structural Dynamics, Vol. 32, No. 3, pp. 369-393, 2003

10）田川健吾，松本芳紀，潘健：弾塑性ばねに支持された剛な建物の地震時 転倒限界, 日本建築学会技術報告集, 第 18 号, pp. 31-34, 2003.12

11) Clough, R. W. and Huckelbridge, A. A.: Preliminary experimental study of seismic uplift of a steel frame, Report No. UBC/EERC-77/22, EERC, University of California, Berkeley, Calif., 1977

12) Huckelbridge, A. A.: Earthquake simulation tests of a nine story steel frame with columns allowed to uplift, Report No. UBC/EERC-77/23, EERC, University of California, Berkeley, Calif., 1977

13）笠井和彦，金田充弘，大熊潔：ステップカラム制振構造の実施例:解析と 実大ダンパー実験，パッシブ制振構造シンポジウム 2001, pp. 235-249, 2001.12

14）岩下敬三, 木村秀樹, 春日康博, 鈴木直幹 : 基礎浮き上がりを伴う鉄骨 架構の振動台実験, 日本建築学会構造系論文集, 第 561 号, pp. 47-54, 2002.11

15）緑川光正, 小豆畑達哉, 石原直, 和田章 : 地震応答低減のためベースプ レートを浮き上がり降伏させた鉄骨架構の動的挙動, 日本建築学会構造系 論文集，第 572 号，pp. 97-104，2003.10

16）岩下敬三，谷口元，石原大雅：杭頭で浮き上がりを許容した建物の地震 応答エネルギー評価, 日本建築学会構造系論文集, 第 564 号, pp. 23-30, 2003.2

17）小豆畑達哉, 緑川光正, 石原直 : 地震応答低減のためベースプレートを 浮き上がり降伏させた鉄骨架構のエネルギー吸収機構と最大応答変位予測, 日本建築学会構造系論文集, 第 583 号, pp. 61-68, 2004.9

18) Midorikawa, M., Azuhata, T., Ishihara, T. and Wada, A.: Shaking table tests on seismic response of steel braced frames with column uplift, Earthquake Engineering and Structural Dynamics, Vol. 35, No. 14, pp. 1767-1785, 2006

19）緑川光正，小豆畑達哉，石原直，川上誠，庄司正弘：ベースプレート降 伏型ロッキングシステム 10 層鉄骨造立体架構の地震応答有限要素法解析, 日本建築学会大会学術講演梗概集， B-2 構造 II, pp. 235-236, 2006.9

20) ADINA R\&D, Inc.: Theory and modeling guide, Report ARD 03-7, 2003

21）緑川光正, 小豆畑達哉, 石原直, 和田章 : 浮き上がり降伏型ベースプレ 一ト大型試験体の静加力実験, 日本建築学会大会学術講演梗概集, B-2 構 造 II, pp. 295-296, 2005.9

22）須藤智文, 緑川光正, 石原直, 小豆畑達哉 : 柱浮き上がり制振構造に用 いる降伏型ベースプレートの履歴特性と累積塑性変形性能, 日本建築学会 大会学術講演梗概集， B-2 構造 II, pp. 475-476, 2007.8

23) Housner, G. W.: Spectrum intensities of strong motion earthquakes, Proc. of 1952 Symposium on Earthquake and Blast Effects on Structures, Earthquake Engineering Research Institute, 1952

24) Arias, A.: A measure of earthquake intensity, Seismic design for nuclear power plants, MIT Press, Cambridge, MA, 1970

25）石原直, 緑川光正, 小豆畑達哉：均一せん断棒による多層建築物の浮き 上がり自由振動解析, 日本建築学会大会学術講演梗概集, B-2 構造 II, pp. 295-296, 2005.9

26）石原直，小豆畑達哉，野口和也，森田高市，緑川光正：層剛性分布を考
慮した多層建築物の浮き上がり地震応答模型実験, 鋼構造年次論文報告集, 第 14 巻, pp. 327-334, 2006.11

27）秋山宏：鉄骨柱脚の而震設計，技報堂出版，1985.3

28）山田哲，秋山宏：柱脚の固定度が鋼構造多層骨組の終局耐震性能に与え

る影響，日本建築学会構造系論文集，第 496 号, pp. 113-118, 1997.6

29）山田哲，秋山宏，貞許美和：スリップ型の復元力特性を有する柱脚の弾 塑性挙動が構構造多層骨組の終局耐震性能に及ぼす影響, 日本建築学会構 造系論文集，第 502 号，pp. 141-147， 1997.12

30）河野昭雄，松井千秋：柱脚の復元力特性の違いがはり降伏型鉄骨ラーメ ンの地震応答性状に与える影響について, 日本建築学会構造系論文集，第 507 号, pp. 139-146, 1998.5

注

注 1) 設計用せん断力（水平力）に対するベースプレートの設計では，4 枚 のウィング (図 3(a)参照) の内, せん断力方向に平行なウィングにおいて は，圧縮側になるウィングを無視して，引張側になるウィングは引張で抵 抗し, せん断力に直交する方向のウィング 2 枚はせん断で抵抗するものと する。

\section{付録 A 地震応答解析より得られた BPYの荷重一変形関係}

$\mathrm{Kobe}(100 \mathrm{~cm} / \mathrm{s}$ ， 3 方向)入力時の BPY モデルの地震応答解析より得られた $\mathrm{X} 1 \mathrm{Y} 2$ 柱 (図 1 参照) に取り付く BPY の柱軸方向力ー浮き上がり変位関係, 曲げモーメントー回転角関係，せん断力ー水平変位関係を図 A1 に示す。こ こで, 変位および回転角は BPY が取り付く柱下端断面の図心位置における值 である。

図(a)の実線は地震応答解析結果，破線は静加力解析結果を，一点鎖線は柱 軸方向力を受けて BPY ウィングの内外端部に塑性ヒンジが生じる時の降伏 耐力を示す。なお，圧縮側の最大軸方向力は図(a)には示されていないが $8160 \mathrm{kN}$ である。柱材の降伏軸方向力 $N_{\mathrm{y}}=14000 \mathrm{kN}$, 全塑性モーメント $M_{p}=2490 \mathrm{kN} \cdot \mathrm{m}$ に比べると， BPY に作用する引張軸方向力，曲げモーメント はそれほど大きな值に達していない。

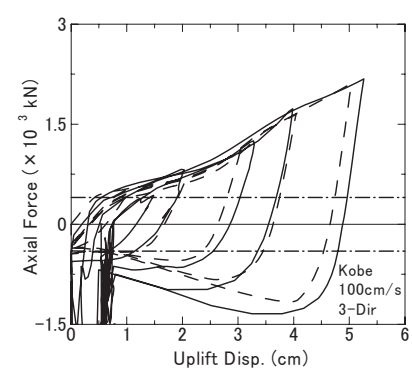

(a) 柱軸方向力-

浮き上がり変位関係
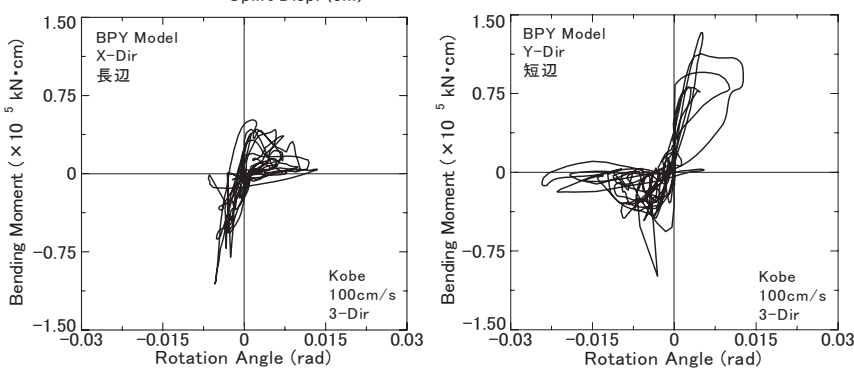

（b）曲げモーメントー回転角関倸
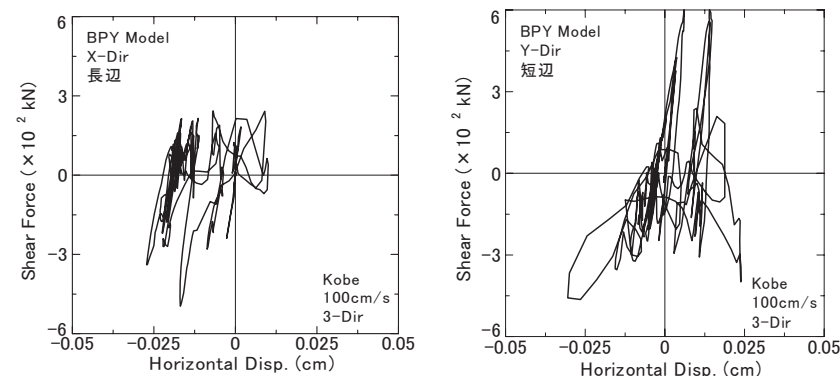

（c）せ九断力一水平変位関係

図 A1 BPY の荷重一変形関係

2008年 6 月10日原稿受理，2008年12月16日採用決定） 